NBER WORKING PAPER SERIES

\title{
(UN)INFORMED COLLEGE AND MAJOR CHOICE: EVIDENCE FROM LINKED SURVEY AND ADMINISTRATIVE DATA
}

\author{
Justine S. Hastings \\ Christopher A. Neilson \\ Anely Ramirez \\ Seth D. Zimmerman \\ Working Paper 21330 \\ http://www.nber.org/papers/w21330 \\ NATIONAL BUREAU OF ECONOMIC RESEARCH \\ 1050 Massachusetts Avenue \\ Cambridge, MA 02138 \\ July 2015
}

We thank Noele Aabye, Phillip Ross, Unika Shrestha, Anthony Thomas, and Lindsey Wilson for outstanding research assistance. We thank Nadia Vasquez, Pablo Maino, Valeria Maino and Jatin Patel for assistance with locating, collecting and digitizing data records. J-PAL Latin America and in particular Elizabeth Coble provided excellent field assistance. We thank Ivan Silva of DEMRE for help locating and accessing data records. We thank the excellent leadership at Chilean Ministry of Education for their ongoing support of these projects, and the outstanding staff for their invaluable support including Loreto Cox Alcaíno, Francisco Lagos, and Rodrigo Rolando. We also thank the outstanding leadership and staff at Servicio de Impuestos Internos for their invaluable assistance. This project was funded solely by Brown University, the Population Studies and Training Center at Brown, and NIA grant P30AG012810. The views expressed herein are those of the authors and do not necessarily reflect the views of the National Bureau of Economic Research.

NBER working papers are circulated for discussion and comment purposes. They have not been peerreviewed or been subject to the review by the NBER Board of Directors that accompanies official NBER publications.

(C) 2015 by Justine S. Hastings, Christopher A. Neilson, Anely Ramirez, and Seth D. Zimmerman. All rights reserved. Short sections of text, not to exceed two paragraphs, may be quoted without explicit permission provided that full credit, including $\odot$ notice, is given to the source. 
(Un)Informed College and Major Choice: Evidence from Linked Survey and Administrative Data

Justine S. Hastings, Christopher A. Neilson, Anely Ramirez, and Seth D. Zimmerman NBER Working Paper No. 21330

July 2015

JEL No. H52,I2,I24,I26,I28,J24

\begin{abstract}
We use large-scale surveys of Chilean college applicants and college students to explore the way students form beliefs about earnings and cost outcomes at different institutions and majors and how these beliefs relate to degree choice and persistence. Linking our survey records to administrative education and earnings data, we compare earnings and cost expectations to observed values for past students and follow survey participants forward to see how beliefs relate to matriculation and dropout outcomes. We find that students have correctly centered but noisy cost expectations, and appear to systematically overestimate earnings outcomes for past graduates. Students who overestimate costs are less likely to matriculate in any degree program and in their stated first-choice program, and are more likely to drop out. Students who overestimate earnings matriculate at similar rates to other students, but choose degree programs where past students have been less likely to graduate, have earned less early in their careers, and have been more likely to default on student loans. Consistent with an informal model of enrollment choice, students with a stated preference for labor market-related degree characteristics are less likely to overestimate earnings outcomes and choose degrees where past students have gone on to earn more, while the opposite is true for students with a stated preference for enjoyment of the curriculum.
\end{abstract}

Justine S. Hastings

Brown University

Department of Economics

64 Waterman Street

Providence, RI 02912

and NBER

justine_hastings@brown.edu

Christopher A. Neilson

Woodrow Wilson School

Princeton University

Firestone Library, Room A2H

Princeton, NJ 08544

and NBER

cneilson@princeton.edu
Anely Ramirez

Consejo Nacional de Educación

Marchant Pereira 844

Providencia

Santiago, Chile

aramirez@cned.cl

Seth D. Zimmerman

Booth School of Business

University of Chicago

5807 S. Woodlawn Avenue

Chicago, IL 60637

and NBER

seth.zimmerman@chicagobooth.edu 


\section{Introduction}

A growing body of evidence suggests that academic, labor market, and cost outcomes for postsecondary students vary widely by institution, field of study, and degree level (Altonji, Blom, and Meghir 2012; Deming, Goldin, and Katz 2012; Zimmerman 2014; Hastings, Neilson, and Zimmerman 2013; Reyes, Rodríguez, and Urzúa 2013; Kirkebøen, Leuven and Mogstad 2014; Beyer et al. 2015; Hastings, Neilson and Zimmerman 2015; Goodman, Hurwitz, and Smith 2015). An implication of these findings is that whether or not students make informed and forward-looking choices about what to study and where may have large effects on the public and private returns to higher education.

This paper uses large-scale surveys of Chilean college applicants and college students to explore the way students form beliefs about earnings and cost outcomes at different degree programs and how these beliefs relate to degree choice and persistence. We administered the surveys in 2011 and 2012 as part of the college application process and college student bus pass application process. A total of 39,154 students participated in the surveys, which were implemented through an online web application in partnership with the Chilean Ministry of Education (Mineduc) and standardized testing authority (DEMRE). ${ }^{1}$ Respondents included students from a broad range of socioeconomic backgrounds and academic achievement levels. The surveys measure financial literacy, loan literacy, information sources, knowledge about earnings and cost fundamentals, and stated reasons for application plans. In addition, we link our survey records to administrative records of college enrollment (as described in Hastings, Neilson and Zimmerman 2013; Hastings, Neilson and Zimmerman 2015; and Beyer et al. 2015). This link allows us to provide descriptive evidence on the relationship between beliefs about earnings and costs at the time of college entry and academic outcomes such as matriculation, college choice, and dropout.

We use these data to evaluate predictions generated by an informal model of enrollment choice. In the model, students applying to college face uncertainty about earnings and cost outcomes at different degree programs (defined here at the institution-major level). Students may choose to alleviate this uncertainty through costly, degree-specific search. Remaining uncertainty about degree attributes is reduced when a student enrolls in a degree program and is able to learn more about it. Model predictions include the following: a) students facing higher search costs, such as those from college-inexperienced backgrounds, should have less accurate beliefs about program attributes, b) students who do not place much value on financial outcomes when making college choices should have less accurate beliefs about

\footnotetext{
${ }^{1}$ Other papers resulting from this partnership are Hastings, Neilson, and Zimmerman (2013), Hastings, Neilson, and Zimmerman (2015), and Beyer et al. 2015. The surveys described here helped inform the design of HNZ (2015). See below for a description of how this paper builds on previous work.
} 
those outcomes, c) students may know very little about desirable degree choices outside of their consideration set, and d) students with inaccurate expectations about earnings and costs should be more likely to enroll in degrees where past students have fared poorly in those dimensions, and more likely to drop out when the uncertainty is resolved.

Our main results are as follows. When asked about the degree programs to which they are most likely to apply, students have noisy expectations about program costs. These expectations are centered on actual cost values. However, students tend to overestimate earnings outcomes for past graduates at their top choice degree programs. On average, students overestimate early-career earnings outcomes for past graduates of their stated top choice by 39.3\%; one quarter of students overestimate this value by at least 63.3\%. Consistent with model predictions, students from low-SES backgrounds have less accurate expectations than other students. Students in all groups tend to believe that their own earnings outcomes conditional on graduating will be similar to outcomes for past graduates. Also consistent with model predictions, students claim little knowledge of high-earning degree programs outside their field of interest.

We next estimate regressions that relate expectation errors to schooling outcomes, controlling for student SES, gender, and test scores. We find that students who overestimate costs by at least $25 \%$ are 5.5 percentage points less likely to matriculate in any degree program (off a base rate of 81.4\%), 7.7 percentage points less likely to matriculate in their stated first choice degree program (off a base rate of 22.0\%), and 3.3 percentage points more likely to drop out after their first year of enrollment (off a base rate of 5.3\%). In contrast, the accuracy of earnings expectations does not predict whether students enroll or, conditional on enrolling, drop out. Instead, students who overestimate earnings outcomes tend to choose degree programs characterized by lower earnings, higher student loan default rates, and lower graduation rates for past students. Though these findings are descriptive, they are broadly consistent with the idea that beliefs about earnings and costs are important determinants of matriculation and persistence outcomes, and may also affect earnings outcomes over the longer run.

Why do some students have inaccurate beliefs about earnings and costs? We explore this question using our survey data on information sources and preferences for different degree attributes. We first describe how preferences and information sources vary by student background. We find that students from low-SES backgrounds are more likely to rely on advertising and publicity and less likely to rely on in-school sources than students from high-SES backgrounds. High-performing students are more likely to rely on government websites providing information about degree programs and less likely to rely on publicity and advertising. In terms of preferences over different degree attributes, low-SES students are more likely to cite costs and financing as key priorities, while high-SES students are more likely to cite an interest in the curriculum. 
Students' stated preferences predict expectations and choice outcomes. Conditional on gender, SES, and test scores, students who focus on earnings or employment outcomes are 3.6 percentage points less likely to overestimate earnings by at least $25 \%$ (compared to a mean rate of $43.6 \%$ ), and choose degree programs with higher earnings for past students. There is little relationship between a preference for earnings or employment and matriculation or dropout outcomes. In contrast, students who claim a strong interest in course curriculum are 3.2 percentage points more likely to overestimate earnings by at least 25\%, and choose degree programs with lower earnings outcomes for past students. Sources of information are in general weakly related to matriculation and degree choice outcomes. One exception is that students who cite government websites as a source of information tend to have more accurate earnings expectations, and choose degree programs characterized by lower default rates.

Our results build on existing work in a number of ways. Most directly, this paper follows Hastings, Neilson, and Zimmerman (2015; henceforth HNZ), which analyzes the outcomes from a largescale informational intervention providing Chilean students in the 2012-2013 applicant cohort with information on degree-specific earnings and cost outcomes. HNZ measure baseline earnings and cost expectations among loan applicants, and develop a model of choice with limited information to explain why information treatment effects are larger or smaller as a function of baseline characteristics such as stated preferences and beliefs about earnings and costs. We add to those findings here by using a broader set of survey results to understand the various factors that may drive inaccurate expectations, and by tracking students forward past matriculation to see whether expectation accuracy and preferences explain dropout outcomes. We also build on Hastings, Neilson, and Zimmerman (2013), which estimates the long-run labor market effects of admission to different degree programs using a large set of discontinuous admissions rules from the 1980s through 2000s, and Beyer et al. (2015), which considers the effects of regulation tying student loan subsidy amounts to observed earnings outcomes.

In addition, our work relates to the literature exploring the potential differential difficulties students from different socioeconomic backgrounds face when considering and applying to higher education degree programs. Important papers in this literature include Avery and Kane (2004), Bettinger et al. (2012), Grodsky and Jones (2007), Dynarski and Scott-Clayton (2008), Hoxby and Avery (2012), Dynarski, Scott-Clayton, and Wiederspan (2013), and Hoxby and Turner (2013, 2015).These papers describe how non-transparent financial aid and admissions policies create barriers to college attendance and persistence, particularly for lower-income students. In contrast, Betts (1996), Arcidiacono, Hotz, and Kang (2012), Zafar (2011), and Wiswall and Zafar (2015) document major-specific earnings expectations for students already enrolled in selective universities in the US, and explore how these relate to major choice. We generally observe larger expectation errors than these authors, perhaps because we focus on students from lower-SES backgrounds. 
Our work also relates to a broader literature using experimental and descriptive approaches to explore how beliefs about earnings and costs affect educational attainment (as opposed to degree choice). Dominitz and Manski (1996), Avery and Kane (2004), Attanasio and Kaufmann (2014) and Kaufmann (2014) provide non-experimental evidence that beliefs about investment returns affect the choice of educational levels. Jensen (2010), Nguyen (2010), Oreopoulos and Dunn (2013), and Dinkelman and Martinez (2014) provide students with information on the earnings and/or cost outcomes associated with different levels of educational attainment, and measure how students change their educational investment decisions in response. Results from these studies indicate that students face substantial uncertainty about the earnings and cost outcomes associated with different levels of attainment, and that informational treatments can affect attainment.

The paper concludes with a discussion of the possible policy implications of our findings. We focus in particular on the implications of our results for the efficacy of disclosure policies of the type currently under consideration in both Chile and the US (HNZ 2015; DOE 2014a).

\section{Informal model of degree choice}

We frame our empirical work with an informal model of degree choice. We describe the ways in which students' preferences and constraints lead them to acquire or fail to acquire information on financial outcomes at different degree programs in a context where a) there are many degree programs to choose from, and b) the search for accurate information is costly. The goal is to generate a set of predictions that can be evaluated using our survey and administrative data.

Upon completing high school and fulfilling the standard set of college entrance requirements, students face the challenge of assembling a portfolio of college applications. Their goal is to maximize the chances of enrolling in a degree program that offers a package of attributes they value, which may include financial characteristics like low costs or high labor market returns, as well as non-financial characteristics like interesting coursework, an appealing peer group, or low travel time. There are many possible degree choices, and students may be uncertain about their characteristics. Students must pay a cost to learn about financial outcomes for past students at a given degree program. This cost could be paid through time-consuming online search, or through queries to friends, relatives, or guidance counselors, and may vary by degree or student background. Students weigh the costs of search against the benefit of choosing a higher-utility degree with some probability, given their preferences, their beliefs about the distribution of attributes across degrees, and their beliefs about the relationship between their own likely 
outcomes and those for past students. Once students arrive at a degree program, at least some of the uncertainty about program attributes is resolved, and students may choose to leave the degree program.

As discussed in Chade and Smith (2006), the portfolio choice problem is a complicated one, and we will not analyze it formally here. We will instead focus on some qualitative implications. Students who value financial outcomes less will be less likely to seek out information on these outcomes. The same will be true for students who value financial outcomes highly but have trouble interpreting information on earnings and costs due to limited financial literacy. Students will also be less likely to try to learn more about degree programs they believe they are unlikely to attend, either because other attributes of the degree are unappealing or because they are unlikely to be admitted. Students who must pay a high cost to learn about high-earning degrees may be less likely to try to learn more about and enroll in such programs. These students may be disproportionately likely to come from low-SES, college-inexperienced backgrounds.

The informal model leads to several qualitative predictions. We focus on five. First, students who face higher search costs (e.g., students from low-SES, college-inexperienced families, neighborhoods, or schools) should have less accurate expectations about college characteristics. Second, students who place relatively low value on earnings or costs in college choice should also have less accurate expectations about these attributes. Third, students should have more knowledge of degree programs closer to their own interests. Fourth, students who have less accurate expectations about earnings or costs or who do not value these outcomes when making degree choices should be more likely to enroll in degree programs where past students have performed poorly along these dimensions. Fifth, students who arrive at degree programs with inaccurate expectations should be more likely to drop out after updating their beliefs.

We note that these predictions are distinct from what we might expect to see under alternate models of the college search process. In models where the search for information about degree programs is costless or undirected, we would not expect to see differences in knowledge of more- and less-preferred programs, differences in expectation errors by proxies for search costs, or a strong relationship between stated preferences for financial outcomes and knowledge of those outcomes. Our empirical specifications seek to highlight and test the extent to which what students know about degree programs at the time of college application arises from a deliberate search process. 


\section{Institutional background}

\subsection{Higher education in Chile}

Chile is a middle-income OECD member country with a higher education system that resembles the US in terms of attainment, subsidy rates, and market structure. Chile is among the richest countries in South America, with a per capita GDP of USD \$15,732 in 2013 (World Bank 2015). 38\% of 25-34 year olds in Chile in 2010 had a tertiary degree, compared to 42\% in the US (OECD 2012). 35.8\% of students enrolling in higher education in Chile received state-backed loans, compared to $40.2 \%$ in the US. ${ }^{2}$ As in the US, higher education institutions in Chile may be public, private non-profit, or private for-profit. A number of corporate parents operate universities in both Chile and the US, including the Apollo Group (owners of University of Phoenix). ${ }^{3}$

The similarity between the educational systems in the US and Chile is a recent development. Prior to 2006, state-backed student loans were only available to poor students attending selective degree programs. ${ }^{4}$ In 2006, Chile introduced a new loan program, the Credit Aval del Estado (CAE). CAE provided loans for use at all accredited tertiary programs to students who a) fell into the lower $80 \%$ of the family income distribution, and b) satisfied either test score requirements (for loans at universities) or grade requirements (for loans at technical or professional schools). CAE loans allow students to borrow up to a degree-specific reference tuition at an interest rate of 2\% (Mineduc 2012b). Program rules stipulate that students pay back their loans over a 15 year period once they leave school. Following the introduction of CAE loans, tertiary enrollment rose by $72 \%$ from about 619,000 prior to program implementation in 2005 to 1.07m in 2011. 274,345 students received CAE loans in 2011, equal to 61\% of enrollment growth since 2005. ${ }^{5}$ As CAE recipients began to enter repayment in the early 2010s, policymakers in Chile faced challenges related to low repayment rates and student unrest. In 2013, the median (enrollment-weighted) degree program had an on-time repayment rate of $50 \%$ and default rate of 33\% among students who had entered repayment (Beyer et al. 2015). Student protests in 2011 and 2012 focused on concerns about privatization and low quality in the higher education system (Barrionuevo 2011).

\footnotetext{
${ }^{2}$ Chile statistics from Mineduc (2012a). Statistics include the two largest student loan programs: CAE and FSCU. US statistics from DOE 2014b.

${ }^{3}$ Apollo Education Group (2015).

${ }^{4}$ These loans were available through the Credito Fondo Solidario (FSCU) loan program.

${ }^{5}$ Mineduc (2012a), pages 82 and 134.
} 


\subsection{Applying to college in Chile}

Students in Chile apply to institution-major specific pairs, which we term degrees. For example, a student might apply to Engineering at the University of Chile, or Anthropology at the University of Valparaiso. Initial field choices are binding. Students wishing to transfer between degree programs must typically drop out, reapply, and start over in the new program. College admission outcomes depend primarily on high school grades and a standardized admissions exam called the Prueba Seleccion Universitaria, or PSU. All students taking the PSU complete math and language exams, and students may also take additional subject tests. Each exam section is scored so that the mean is 500 and the standard deviation is approximately 100. Scores range from 150 to 850. Students take the PSU in early December following their senior year of high school, and results are reported in late December. The earliest application deadlines fall early in January, and applications for some schools continue until March, when the new academic year begins. Compared to the US, the application timeline is compressed: students learn about their exam scores and make application choices within a matter of weeks.

Applications typically do not weight difficult-to-assess items like essays or community service. At many schools in Chile, admissions outcomes depend only on a weighted index of grades and test scores (see Hastings, Nielson, and Zimmerman 2013). This makes it relatively easy for many applicants to assess their admissions chances at different degree programs given knowledge of their scores. Similarly, because eligibility for the primary state-backed loan and grant programs (including CAE loans) depends only on broad income grouping and test scores (see OECD 2009, pp. 104-109), students can typically determine the amount of state-backed aid for which they will be eligible by early January.

\section{Surveys and data}

\subsection{Surveys}

We present results from two surveys. The first is the Proyecto 3E pilot survey. Proyecto 3E is the broader label given to our collaboration with Mineduc to study college choice and labor market outcomes in Chile. ${ }^{6}$ We implemented this survey as a test run for an informational intervention conducted the following year. See HNZ (2015) for a description. The sample for the survey was drawn from the population of PSU 2012 registrants who graduated from high school in 2010 or later. The sample

\footnotetext{
${ }^{6}$ Proyecto 3E got its name from the Spanish-language acronym for the three core foci of the project: students (estudiantes), education, and expectations.
} 
excluded students from top-performing private schools. Respondents were recruited via email invites sent from the Chilean testing authority (DEMRE) in two waves, the first before the PSU exams in early December 2011 and the second after the PSU exams. We followed initial invitations with text message and email reminders to participate.

The survey included questions on students' institution and career choices, the key factors they considered when making these choices, and their sources of information about degree programs. In addition, we asked students about cost expectations and about major- and institution-type- specific earnings expectations for themselves, for graduates with similar characteristics to their own, and for the average graduate. Students were not offered any compensation for taking the survey. A total of 12,730 respondents took the survey, though only 7,382 completed it in full (we drop 19 cases in which a student completed the survey more than once).

The second survey is the Tarjeta Nacional Estudantil (TNE) survey, conducted between March and December 2012. The TNE survey took place in three waves. Respondents for the first wave of the TNE survey were recruited from the population of first-year postsecondary students. These students were contacted using email invitations from school administrators. In the remaining waves, we additionally recruited students from the population of students who had graduated from high school in 2011 or earlier and either registered for the PSU or applied for state-subsidized financial aid in 2012. We recruited these students via emails sent through DEMRE. The survey questions focused on informed decision making, resources used to finance studies, knowledge of loan terms, and financial literacy. Participants were offered a chance to win an iPad 2 from a raffle as compensation. A total of 26,424 respondents took the TNE survey. See the Online Appendix for the text of the Proyecto 3E pilot and TNE surveys. ${ }^{7}$

\subsection{Administrative data}

We supplement our survey data with administrative data on education and earnings. Our educational data include basic student demographics, administrative records of high school graduation outcomes beginning in 1995, college enrollment and graduation records from the year 2000 and onward, entrance exam outcomes from 1980 and forward, and data on education costs for the 2012 school year. A variable of particular importance for our analysis is a high-school level SES ranking constructed by Mineduc. This ranking divides high schools into five categories, labeled A through E, based on parental income levels. Since we do not systematically observe parental income, we use these high school rankings to split students into low- and high-SES categories. The low-SES category includes the roughly one third of

\footnotetext{
${ }^{7}$ See http://www.justinehastings.com/images/downloads/HNZ_UninformedChoice_Appendix.pdf for the Online Appendix.
} 
students in A- and B-ranked schools. Our semester-level college enrollment data allow us to track survey participants forward to see where they enroll and whether they persist.

We use administrative categories to classify institution types and majors. Mineduc divides higher education institutions into three main types: technical schools (CFTs) offer two- to three-year technical degrees, professional institutes (IPs) offer both technical and vocationally-oriented four-year degrees, while universities offer traditional undergraduate and graduate degrees. ${ }^{8}$ In 2012, universities held 58.4\% of all undergraduate matriculation while professional institutes and technical schools had $28.2 \%$ and 13.4\%, respectively. Mineduc also classifies degrees by field using a set of 192 subject-by-degree level categories. ${ }^{9}$ These categories are fairly specific. Examples include "graphic design" or "accounting auditor.” We use these categories to define college majors. See the Online Appendix for a list of majors.

We link our education records to administrative tax data from the Servicio de Impuestos Internos (SII). These records include earnings outcomes for the years 2005 to 2011. We are able to access these data only within SII offices in Santiago. ${ }^{10}$ We consider a broad measure of income, which includes income from wages, salaries, partnerships, investment, and retirement income. See Hastings, Neilson, and Zimmerman (2013) for a detailed description of the components of the tax forms used to construct this measure. Our surveys ask students about earnings expectations (for themselves, for peers of the same gender and test score group, and for all graduates) conditional on graduating from a given institution type with a given major and "starting a stable, full time job.” We compare responses to this question to (inflation-adjusted) observed outcomes for 2000 through 2010 graduates of the stated major and demographic/score group in their first and second years after graduation who are employed at least 10 months out of the year. Score groups consist of five broad tiers based on the median score of admitted students. ${ }^{11}$

When evaluating students' enrollment choices, we use finer-grained earnings measures developed in HNZ (2015). We base these measures on OLS estimates of earnings outcomes conditional on enrollment in institution-major pairs (as opposed to graduation from institution type-selectivity group-

\footnotetext{
${ }^{8}$ Some universities, particularly public universities, also offer two-year technical degrees.

${ }^{9}$ These categories were developed under the auspices of the Futuro Laboral program in Chile, which aims to collect and disseminate information on degree-specific labor market outcomes. See Futuro Laboral (2015).

${ }^{10}$ This disclosure is required by the Chilean government. SOURCE: Information contained herein comes from taxpayers' records obtained by the Chilean Internal Revenue Service (Servicio de Impuestos Internos), which was collected for tax purposes. Let the record state that the Internal Revenue Service assumes no responsibility or guarantee of any kind from the use or application made of the aforementioned information, especially in regard to the accuracy, validity or integrity.

${ }^{11}$ The details of the benchmarking process are as follows. Degree programs (defined at the institution-major level) are divided into five groups based on the median score of admitted students and type of degree. The first group consists of all technical degrees. The second group consists of non-technical degrees for which there is no entrance exam data or for which the median student scores between 0 and 450 points on the combined math and reading PSU. The third, fourth, and fifth categories encompass score ranges of 450 to 525, 525-600, and 600-850, respectively. We take the graduate-weighted average for students of a given gender across all degrees in a score category and benchmark students' expectations against the major-tier-gender specific cell means.
} 
major). We choose a flexible functional form that allows for interactions between degree program attributes like major and selectivity tier and student characteristics including gender, academic ability, and socioeconomic status. We use the OLS estimates to compute predicted earnings outcomes at age 26 for students in gender-SES-ability cells at each institution-major pair. In what follows, we will refer to these values at the degree program in which a student chooses to enroll as "predicted earnings.” See HNZ (2015) for additional details on this procedure.

We also evaluate enrollment choices using graduation rates and student loan default rates for previous students. We use measures of degree-level graduation rates and student loan repayment and default rates developed in Beyer et al. (2015); see section 6 of the Online Appendix for additional discussion. We construct degree-specific graduation rates using administrative enrollment and graduation data for the 2000 through 2005 entering cohorts. We compute degree-specific default rates using data on CAE loan repayment. Because the CAE loan program is relatively new, there are some degree programs where few students have had the necessary time to complete or leave their degree program and enter repayment. Our findings here should therefore be regarded as preliminary.

\section{Results}

\subsection{Data description}

Table 1 compares the student samples in the P3E 2011 and TNE surveys to the broader student population. Students select positively into the P3E sample. They outscore the population of PSU takers by more than 40 points on the average of math and language PSU sections, and are 13.1 percentage points (39\%) less likely to come from low-SES high schools. They are less likely to come from municipal (public) high schools and more likely to come from voucher schools. See Neilson (2013) for a discussion of public, private, and voucher primary and secondary schools in Chile. They are more likely to be women, and more likely to have graduated from high school prior to 2011. Similar patterns emerge in the TNE sample. The finding that more able students select into survey completion is similar to survey results presented in HNZ (2015).

\subsection{Cost and earnings expectations}

Table 2 describes students' earnings and cost expectations for their stated first-choice degree programs. The top panel of Table 2 describes the difference between students' beliefs about annual costs of 
attendance and the administrative values we observe in the data. This panel uses data from the 3E pilot survey. Students were asked to drag a slider to the value corresponding to annual tuition and fees at the listed degree, or to check a box stating "I do not know.” We present results as percentage deviations from observed annual tuition values (i.e., $100 \times($ Reported - Benchmark $) /$ Benchmark $)$. In addition, in this and several following tables, we report results from statistical tests of the equality of listed moments of the error distribution across SES and ability groups. Significance indicators in the high-SES category correspond to tests of equality with the low-SES value; significance indicators from the medium- and high-scoring categories correspond to tests of equality with the low-scoring category. In this and following tables, sample sizes used for different calculations vary depending on match rates to administrative data and how many students provided the required survey responses.

In the full sample, $39.6 \%$ of students claim not to know about costs at their first choice degree programs. Students from low-SES backgrounds are 10.6 percentage points (46.7\% versus $36.1 \%$ ) more likely than high SES students to claim not to know about degree costs. Students with low PSU scores are 19.2 percentage points (48.2\% versus $29.0 \%$ ) more likely than high-performing students to claim no knowledge of costs. Respondents' stated cost expectations are centered around the values observed in the administrative data: overall, $50 \%$ of students have cost expectations within roughly $11 \%$ of the observed cost value. Low-SES and low-performing students have noisier cost expectations. The interquartile error range is 27.5 percentage points for low-SES students and 20.3 percentage points for high-SES students. This difference is statistically significant at the $1 \%$ level. Cross-SES and cross-achievement differences in stated knowledge of costs and in moments of the error distribution are in general also statistically significant, with the exception of cross-SES gaps in the lower quantiles of the belief distribution. We add one caveat to this analysis: because we do not have access to data on individual-specific institutional aid that students may receive, it is possible that what we interpret as expectation errors in part reflect real differences in costs.

Students' beliefs about earnings outcomes for past graduates are less accurate than their beliefs about costs. The second panel of Table 2 reports students' responses to questions about earnings outcomes for past graduates of the same gender and similar test scores at their top choice major-institution type combination. Students supplied responses by dragging a slider to the position corresponding to their expected monthly earnings value for the listed group. In contrast to the costs question, students were not allowed to respond "I don’t know," although they were able to skip the question by clicking "Next." 12 We benchmark these values to observed outcomes for same-gender past graduates from that major-institution

\footnotetext{
${ }^{12}$ Students who skipped earnings expectation questions are included in the non-response group. We note that the absence of an "I don’t know" button in the earnings expectations question makes comparisons of non-response rates on the earnings and costs questions difficult.
} 
type whose PSU scores are similar to those the respondent expects to receive. In the full sample, $12.2 \%$ of students do not report expectations. Those that do report expectations overestimate earnings by an average of $39.3 \%$ relative to the benchmark value for past students, with $25 \%$ of students overestimating earnings outcomes by at least $63.3 \%$. Average errors for low-SES students are slightly higher than those for high-SES students, and more broadly dispersed. The interquartile range in belief errors is 78.8 percentage points for low-SES students compared to 70.3 percentage points for high-SES students. This difference is statistically significant at the $1 \%$ level. Students with low entrance exam scores tend to overestimate earnings outcomes by more than higher-performing students. The upper quartile expectation error for low-scoring students is $86.4 \%$. This contrasts with an upper-quartile error of $51.4 \%$ for the highest-performing students; we reject the hypothesis that these two values are equal at the $1 \%$ level.

The third panel of Table 2 describes students' responses to questions about expected own earnings conditional on graduation from their first choice major-institution type pair, here benchmarked to observed outcomes for students in that major-institution type of the same gender whose PSU scores are similar to those the respondent actually receives. Results here are similar to those in Panel 2. 4.7\% of students do not report own earnings expectations. Low-SES students believe their earnings will be slightly higher relative to those for past students than do high-SES students, and the dispersion of percentage differences from the benchmark is also greater for low-SES students. Students do not strongly differentiate their own earnings expectations from their expectations for other graduates in the same gender and test score group. As shown in the fourth panel of Table 2, students from all backgrounds on average believe that their earnings will be fairly similar to those for past students at the same gender and test score level.

Our findings on earnings expectations indicate that students a) overestimate earnings outcomes for past graduates observably similar to themselves and b) think their own earnings will be similar to their overestimates for past graduates. Differences between expectations about own earnings and observed values for past graduates are larger for low-SES and low-scoring students than in the population at large. These findings are broadly similar to those in HNZ (2015) and suggest that students have inaccurately optimistic beliefs about their own earnings prospects at their top-choice degrees. ${ }^{13}$ We note, however, that it is difficult to rule out the possibility that students' own expectations are correct even though they appear to overestimate earnings outcomes for past students. Our estimates are substantially larger than the major- (but not institution type- or test score-) specific error estimates reported in Wiswall and Zafar (2015), who study a sample of NYU undergraduates. Students may have less knowledge of earnings

\footnotetext{
${ }^{13}$ HNZ (2015) reports larger cross-SES gaps in earnings expectations. This is likely because HNZ (2015) asks students about institution-major specific earnings outcomes, while here we focus on major-institution type-gender-ability level outcomes. This finding is what we would expect if low-SES students within a major-gender-ability group choose institutions characterized by lower average earnings, but do not appropriately adjust their reported earnings expectations for this difference.
} 
outcomes conditional on academic achievement, gender, and degree level as well as major; in addition, the sample of applicants we survey come from lower-SES backgrounds and by definition have less college experience than already-enrolled undergraduates. Compared to their relatively accurate cost expectations, students appear to have a weaker grasp of the earnings outcomes at different degree programs.

\subsection{Knowledge of alternate degree programs}

Our informal model of search suggests that students will know more about more-preferred degree programs than about potential alternatives. This is consistent with what we see in the data. The P3E pilot fed each respondent's majors of choice, PSU scores, and gender into a program that randomly selected up to three alternative majors from the top-quartile earnings or bottom-quartile debt- to-earnings ratio majors in the same broad areas as the chosen majors for a same-gender student in the respondent's PSU score range. The program also selected three to six high-earning or low debt-to-earnings majors from other broad areas. ${ }^{14}$ We asked students how familiar they were with each suggested major. Students were allowed to select from a menu of responses ranging from never having heard of the major to knowing a great deal about it.

Table 3 describes students' responses. We find that students claim much more knowledge of majors in the same field of study as their first-choice major than of majors in other fields. Low-SES and low-performing students are less likely to claim knowledge of alternate majors in the same area. However, there is relatively little difference in knowledge of majors outside one's first-choice fields by SES background or academic achievement. The fraction of students who claim to know a lot about majors from fields other than their own is only about 5-7\% across SES and achievement categories. These findings suggest that one factor limiting access to degree programs characterized by high earnings and low debt is that limited search leads to many students not knowing much about these programs.

\subsection{Consequences of expectation errors}

\footnotetext{
${ }^{14}$ We use CINE UNESCO (Normalized International Classification of Education) field classifications. The classification has ten categories: Agriculture, Art and Architecture, Basic Science, Business Administration, Education, Health, Humanities, Law, Social Science, and Technology. The randomly selected high-earning-careers-for-you were always different than the respondent's top 3 choices. If the respondent chose a high-earning career, another high-earning career was displayed. The alternative careers were displayed on the screen for the respondents, and respondents were asked how familiar they were with each alternative career. After this question, the program displayed three to six high-earning-careers-for-you (depending on the number of alternative careers shown from the same field as respondents' chosen careers) randomly selected from the top 12 careers, based on either earnings or debt-to-earnings ratio, from any broad field. If only two careers from the respondent's chosen field(s) were displayed in the first step, then four alternative careers were displayed regardless of field to suggest a total of six alternative careers in every case.
} 
Expectation errors are important to the extent that they lead students to make educational choices different than those they would have made with accurate information. Table 4 explores how expectation errors in first-choice degree earnings and first-choice degree costs correlate with college enrollment and persistence, as well as with characteristics of the degree programs students choose. Our approach is to compare outcomes for students who believe their own earnings (cost) outcomes will be $25 \%$ or more above the benchmark value and students who believe their earnings (cost) outcomes will be $25 \%$ or more below the benchmark value to students with expectations that fell within $25 \%$ of the benchmark value. $43.6 \%$ of students overestimate earnings by at least $25 \%$, while $16.1 \%$ underestimate earnings by this amount. The figures for costs are $13.9 \%$ and $9.2 \%$, respectively.

We emphasize that the relationships we document here are descriptive. If expectation errors are correlated with other individual attributes that affect enrollment and persistence outcomes, our estimates will not capture causal effects. We partially address this concern by including controls for student SES background, gender, and academic ability (as measured by second-degree polynomials in PSU scores). We focus on linear probability models of matriculation, matriculation to the first choice degree, and dropout by the beginning of the second year (conditional on first-year enrollment). We also estimate models in which the outcome variables are predicted age 26 earnings for past students enrolling in the chosen degree program, student loan default rate at the degree, and degree graduation rate.

We find that expectation errors predict a variety of educational outcomes. Compared to students whose cost beliefs are approximately accurate, students who overestimate costs by at least $25 \%$ are 5.5 percentage points less likely to matriculate in any degree program, 7.7 percentage points less likely to matriculate in their first choice, and 3.3 percentage points more likely to drop out if they do enroll. These figures are relative to mean rates of $81.4 \%, 22.0 \%$, and 5.3\%, respectively. They choose to enroll in degree programs where the default rate for past students is 1.8 percentage points higher, compared to a mean rate of $25.4 \%$. The finding that students who overestimate costs are more likely to drop out is somewhat surprising. Our informal model might lead one to expect that students who underestimate costs prior to enrollment and update cost beliefs upward following enrollment would be more likely to choose to leave. One explanation for the result we observe is that students do not fully update cost overestimates downward even after enrolling (perhaps due to limited financial literacy; we discuss this below). The result may also be attributable to other determinants of dropout that are correlated with cost overestimates.

Earnings expectation errors are not strongly related to matriculation or dropout outcomes, but students who overestimate earnings outcomes at their first-choice major by at least $25 \%$ do enroll in degree programs where default rates for past students are 2.3 percentage points higher and graduation rates are 2.1 percentage points lower (relative to base rates of $25.4 \%$ and $62.1 \%$ ). Predicted earnings at 
age 26 for demographically similar students are roughly \$80,000 Chilean pesos (CLP) lower (relative to a base of just over $\$ 500,000 \mathrm{CLP}$ ) at the degrees chosen by students who overestimate their own earnings. ${ }^{15}$

Qualitatively, these findings are consistent with Hoxby and Turner (2013), who find that interventions which include efforts to correct inaccurately high cost expectations can raise student enrollment rates in selective schools. One way to compare our findings with those from previous work is in terms of the elasticities of matriculation in the stated first choice degree and matriculation in any degree program with respect to beliefs about earnings and costs. These comparisons should be made cautiously, as our estimates of elasticities are potentially biased by correlations between beliefs and other determinants of enrollment behavior, conditional on students expressing a strong preference for the listed degree program. Students who list a given degree first despite believing it offers low earnings or high costs presumably do so because it has other attributes they find desirable. Online Appendix Table A3 reports estimated elasticities of matriculation decisions with respect to beliefs about first choice earnings and costs. These estimates come from regressions of matriculation outcomes on beliefs about earnings and costs at the listed first choice degree program, controlling for test scores, SES, and gender as above. The elasticities of any matriculation and first-choice matriculation with respect to costs at the mean values of cost expectations and enrollment rates are 0.19 and 0.97, respectively. Students' first-choice enrollment is more sensitive to expected costs at that degree program than overall enrollment. For comparison, Dynarski (2003) estimates the elasticity of college attendance with respect to college costs (including the opportunity costs) at about 1.5; Cameron and Heckman (2001) report estimated effects suggesting smaller elasticities. $^{16}$

Matriculation rates on average decline slightly with earnings expectations. Compared to costs, elasticities are small, at 0.03 for overall enrollment and 0.22 for first-choice enrollment. These findings seem very likely to be the result of selection rather than a preference for low earnings. Students who overestimate earnings by a large margin may have a weak grasp on the college admissions process more broadly, and degrees with low earnings that students nevertheless rank first among their preferences may have other desirable attributes. Our findings differ from the literature on college major choice, which reports small but positive elasticities with respect to earnings expectations and observed outcomes (Wiswall and Zafar 2015; Beffy, Fougére, and Maurel 2012). They also contrast with findings suggesting

\footnotetext{
${ }^{15}$ A concern here is that the predicted earnings effect may arise because higher values of true earnings outcomes at the first choice degree mechanically reduce expectation errors (or result in larger negative expectation errors). However, as shown in Online Appendix Table A2, our findings are qualitatively unchanged by conditioning on benchmark values of earnings and costs at students' stated first choice degree program. We prefer to present specifications without these controls in the main text, because stated preferences at the time of the survey are likely an important channel through which expectations influence ultimate enrollment outcomes.

${ }^{16}$ For example, Cameron and Heckman report that a \$1,000 increase in tuition at two-year colleges reduces two-year enrollment by 10 percentage points for white students; at the reported mean tuition value of $\$ 888$ and enrollment rate of 0.26 , this would imply an elasticity of enrollment with respect to direct costs of 0.34 .
} 
that subjective beliefs about the returns to college more broadly affect college enrollment (see, most recently, Kaufmann 2014). We emphasize that we interpret this discrepancy with caution.

\subsection{Determinants of expectation errors}

Inaccurate beliefs about earnings and costs are associated with a choice of lower-earning, higher-default degree programs and with increased dropout rates. Our informal model suggests that students' expectation errors arise because students a) may not have access to accurate information about earnings and cost outcomes (high cost of information acquisition), or b) may not value or understand the financial consequences of college choices at the point when they make application and enrollment decisions (low value of search). In this section we explore students' information sources, preferences, and financial literacy, and relate these to expectation errors and matriculation choices.

Table 5 describes students' sources of information on degree programs. Students were asked to rank different sources of information in terms of their importance in degree choice. The values reported in each cell represent the percentage of students listing the information sources listed in the rows among their top three. ${ }^{17}$ As in previous tables, we report results from statistical tests of the hypothesis that crossSES and cross-ability differences in the share of students identifying a source of information as important are equal. Students consider a variety of sources, but appear to rely most heavily on their peers and family, and on conferences at school (e.g., college fairs). Information sources differ somewhat by student type. Low-SES students are less likely to rely on conferences at school and somewhat more likely to rely on publicity and advertisements. The finding that poor students are more likely to have to look outside of their school for information mirrors Hoxby and Avery (2012) and Hoxby and Turner (2013; 2015).

A second reason for limited search may be that students make enrollment decisions based primarily on attributes other than financial outcomes. Table 6 presents results from a survey question in which we asked students to identify their top priorities when choosing which institution to attend and which major to enroll in. The upper panel of Table 6 reports the fraction of students who counted the factors listed in the rows among their top three priorities. When thinking about institution choice, students appear to focus most strongly on prestige and accreditation. $63.6 \%$ of students list prestige among their top priorities, and $60.8 \%$ list accreditation. For comparison, just over one third of students list

\footnotetext{
${ }^{17}$ Results presented in Tables 5 and 6 combine data from the 3E and TNE surveys. In Table 5 and the upper panel of Table 6 , students in the 3E and TNE surveys were prompted with slightly different lists of information sources and institution characteristics. Further, in all panels, similar responses are aggregated into broader categories. For example, responses mentioning different government websites are aggregated into the "government websites" category. Results reported here reflect the percentage of students identifying an information source (institution characteristic) of the listed type as important, out of those who had the option to choose a source (characteristic) of that type. For this reason sample sizes vary across rows, and the columns in Table 5 and Table 6 need not sum to 300. See table notes and the Online Appendix for more details.
} 
employment prospects as among their top priorities, 23.8\% list low costs, and 11.1\% list future earnings. 25.7\% list curriculum offerings. The lower panel of Table 6 asks the same question but about major choice. The most commonly listed choice priority is enjoying the type of work in jobs associated with the major. $84.1 \%$ of students list this among their top three priorities. $29.0 \%$ of students list future earnings among the top three drivers of major choice, while $43.5 \%$ list employment prospects. $36.7 \%$ list enjoying the curriculum as a top priority. Preferences for earnings, employment, and cost outcomes play an important role in student choice, but compete with a variety of other concerns, in particular preferences for coursework or occupation. ${ }^{18}$

Preferences diverge by ability and SES background. Low-SES students are more likely than highSES students to list costs and financing as important priorities, and somewhat less likely to list future earnings. Lower ability students are less likely to list prestige and more likely to list accreditation among their top priorities, and are also somewhat less likely to list high future earnings. In the context of the informal model, this is consistent with our finding that these students have less accurate earnings expectations. Our broad finding that non-pecuniary factors play a key role in major choice mirrors results for US college students reported in Zafar (2013) and Wiswall and Zafar (2015). We add new evidence indicating that earnings outcomes may play a smaller role in choice for low-SES and low-performing students than the high-performing students previously studied.

Limited ability to interpret information on earnings and cost outcomes may also diminish the incentive to learn about these values. The TNE survey asked students two questions designed to determine whether they understood how to compute the accrual of interest and the effects of inflation. We choose standard formulations as in Lusardi and Mitchell (2011). ${ }^{19}$ Students may claim not to know the answer to each question.

As shown in the upper panel of Table 7, many students claim not to know the answers to basic financial literacy questions, and on average those who do respond answer fewer than half of questions correctly. Students who provide responses on average perform slightly better than random guessing. ${ }^{20}$ High-performing students generally outscore low-performing students on these measures. The lower panel of Table 7 presents results from questions asking students about the terms of CAE loans. Our

\footnotetext{
${ }^{18}$ Online Appendix Table A4 provides additional evidence to this effect. It presents results from a hypothetical question asking students whether they would change their degree choices in response to hypothetical shifts in earnings for their first choice major. $94.3 \%$ of respondents claim they would not switch degree choice in response to a $10 \%$ drop in earnings, and $43 \%$ would not switch in response to a $50 \%$ drop.

${ }^{19}$ The interest rate question was: "Suppose that you have 100 pesos in a savings account, and the interest rate that you earn for those savings is $2 \%$ per year. If you keep the money in the account for 5 years, how much will you have when the 5 years are over?” Students were asked to choose between four options: exactly 100 pesos, more or less than 110 pesos, or “I don't know.” The inflation rate question was "Imagine that the interest rate on the savings account is $1 \%$ annually, and the inflation rate is $2 \%$ annually. After a year, how much can you buy with the money in that account?” Students were asked to choose between four options: more than today, less than today, the same as today, or “I don't know."

${ }^{20}$ Statistically, we are able to differentiate observed rates of correct response from what would be expected under random guessing at the $1 \%$ level.
} 
findings here are similar, except that we do not observe as large a gap between high- and low-performing students. See Online Appendix Table A5 for results broken out by specific literacy questions.

\subsection{Preferences, information sources, and college choice}

Our informal model predicts that students who prioritize non-financial degree attributes should have less accurate earnings and cost expectations, as should students who have difficulty accessing or interpreting information on earnings and costs. We evaluate these predictions using regressions of earnings and cost expectation errors on a set of indicator variables for students' stated information sources and choice priorities. We also consider the relationship between information sources and preferences and enrollment outcomes. We present our results in Tables 8 and 9. For parsimony, we restrict this analysis to a subset of the information source and preference variables. We focus on sources of information for which we observed differential use by student SES background, as documented in Table 5. We focus on preferences that capture the tradeoff between financial outcomes like costs, financing, employment, and earnings, and enjoyment of other degree attributes, like the coursework and the occupation associated with the major. ${ }^{21}$ As above, all specifications include additional controls for student socioeconomic status, gender, and polynomial terms in test score.

The upper panels of Tables 8 and 9 present estimates of the relationship between information sources, and, respectively, expectation and degree choice outcomes. Overall, we find that the sources of information students use to learn about different degree programs have a fairly weak relationship with their expectations and choices. One information source that stands out is government websites. Students who list government websites as important sources report more accurate earnings expectations, and are less likely to underestimate costs. They are 2.3 percentage points (on a base of $22.0 \%$ ) less likely to matriculate in their first choice degree program, and conditional on matriculation choose degree programs where default rates for past students are 1.4 percentage points (on a base of 25.4\%) lower. Visits to an institution and (perhaps surprisingly) the use of publicity and advertisements predict more accurate cost expectations.

The lower panels of Tables 8 and 9 present estimates for students' stated preferences over degree characteristics. We find that students who value earnings or employment opportunities are 3.6 percentage points (compared to mean value of 43.6\%) less likely to overestimate earnings outcomes for past students. Students who value another aspect of labor market outcomes—enjoyment of the associated occupationare more likely to have reasonably accurate earnings expectations. In contrast, students who focus on

\footnotetext{
${ }^{21}$ The relationship between these outcomes and the financial literacy measures reported in Table 7 are also of interest. However, the financial literacy results are taken from the TNE survey of students already enrolled in college. We prefer to focus here on a sample of students in the process of making the college choice.
} 
enjoyment of the school curriculum are about 3.2 percentage points more likely to overestimate earnings outcomes and 3.2 percentage points (on a base of $40.3 \%$ ) less likely to have reasonably accurate expectations.

Preferences for these degree characteristics do not in general predict matriculation, matriculation in the first choice degree, or dropout following the first year (though a preference for curriculum offering, is associated with a 2.4 percentage point increase in the probability of any matriculation and a preference for type of work with a 1.9 percentage point increase in the probability of matriculation at the first choice degree). However, they do predict attributes of the degrees that students choose. Students who value earnings and employment outcomes choose degree programs where demographically similar past students have earned roughly \$41,000 CLP more per month, while students who value enjoyment of coursework choose degrees where past students have earned roughly \$34,000 CLP per year less. Recall that this is relative to a mean value of roughly $\$ 500,000$ CLP. Interestingly, although students who value occupational fit are more likely to have accurate earnings expectations, they choose lower-earning degrees. These students express an interest in labor market outcomes and may learn about these outcomes, but ultimately earnings do not appear to be the key determinants of degree choice. A preference for financing availability has little correlation with expectation or enrollment outcomes. Students who state a preference for low-cost degrees are no more or less likely to have accurate earnings expectations, but are more likely to overestimate costs. This is inconsistent with our informal model but may be attributable to reverse causation-believing that costs are very high may cause students to worry about them more. Students who are focused on costs choose lower earning degree programs with slightly higher default rates and slightly lower graduation rates.

\section{Conclusions}

This paper considers the causes and consequences of uninformed college choice. We describe the results of several surveys in which we asked college applicants in Chile about preferences, earnings, and cost expectations at their preferred degree programs. We benchmark our survey results to administrative tax data, and track students forward using administrative enrollment data to see how expectation errors predict college matriculation and persistence. We guide our analysis of survey results using a framework in which students must pay a cost to learn about degree-specific financial outcomes. This framework suggests that students should be more informed about their preferred degree programs than about less- 
preferred alternatives, and, all else equal, that strong non-pecuniary preferences, high search costs, and limited financial literacy should tend to reduce search for information about financial outcomes.

We find that students tend to have relatively accurate cost expectations, but that students overestimate earnings outcomes for past graduates of their top choice degree programs relative to observed earnings data. Students think that, conditional on graduation, their own earnings will be relatively similar to their (over-) estimates of earnings for past graduates. Consistent with predictions from a model of costly search, students appear to have relatively little knowledge of degree programs outside of their preferred list. Expectation errors are associated with observed educational outcomes. Students with higher estimates of costs are less likely to matriculate in any degree program or their first choice degree program. Students with higher earnings estimates tend to matriculate in degree programs where past enrollees have gone on to earn less, graduate less, and default more often on their student loans. This is true even after controlling for socioeconomic status, gender, and academic ability. Our surveys suggest a number of factors that might limit the intensity of search for financial characteristics, including a limited preference for earnings compared to coursework or occupational fit. Students who focus on labor market outcomes when making enrollment choices are less likely to overestimate earnings outcomes for past graduates of their preferred degree, and tend to choose degree programs with higher earnings outcomes for past students, while the opposite is true for students who focus on a preference for coursework.

Given the absence of exogenous variation in students' information sets, we view our findings as descriptive. However, we believe they offer some insights for policymakers seeking to guide students towards higher-return educational investments. Policymakers in both the US and Chile have generally focused on two types of policies: disclosure policies that provide information to students about financial outcomes at different degree programs, and regulatory policies that penalize programs whose students suffer from low earnings or high rates of default (see HNZ 2015 and Beyer et al. 2015 for a discussion of Chilean policy; DOE 2014a and White House 2014 for the US). HNZ (2015) describe an informational intervention that closes a substantial portion of the gap in predicted earnings between college applicants from low- and high-SES backgrounds at the same test score level, but also show that this effect is fairly small relative to the potential gains from choosing the highest-earning available degree in a similar field. Our survey evidence here is consistent with this finding. It provides support for the idea that students with access to publicly provided information on different degree programs can form more accurate expectations and perhaps realize better outcomes, but also that many students make choices based on nonfinancial degree attributes. Accurate information about low-priority degree characteristics need not change choices for such students. 
Finally, it is important to ask whether or not findings from this study can be extrapolated to other contexts. Chile differs from the US in that there is a larger gap between rates of educational attainment for parents and children. Though rates of educational attainment for younger Chileans are similar to those in the US, rates for older Chileans are lower; 19\% of Chileans between 55 and 64 in 2010 had a tertiary degree, compared to $41 \%$ in the US (OECD 2012). Beliefs and preferences for Chilean students may more closely resemble those for first-time college students or students from college-inexperienced neighborhoods or schools in the US than they do the broader population. The results we present here are likely most relevant for this group.

Further, while the college application process in Chile is generally more transparent than in the US, the compressed nature of the process forces students to make choices about what to study without as much opportunity to learn from college experience as in some US institutions. Admissions outcomes and access to the main financial aid programs in Chile are determined by simple formulas based on grades, test scores, and (for financial aid) broad income categories. This may make it easier for students in Chile to form accurate expectations about admissions outcomes and net costs than students in the US (Dynarski and Scott-Clayton 2008; Dynarski, Scott-Clayton, and Weiderspan 2013). However, to the extent that students continue to learn about their own abilities or the labor market outcomes associated with different major choices after arriving at college (Betts 1996; Malamud 2011; Stinebrickner and Stinebrickner 2014; Bordon and Fu forthcoming), Chilean students may face challenges that US students enrolling in universities with a liberal arts focus do not. The Chilean case may be more relevant for US students considering narrowly-focused vocational programs. An analysis along the lines of this one or of HNZ (2015) in the US context is a topic for future work. 


\section{References}

Altonji, Joseph G, Erica Blom, and Costas Meghir. 2012. "Heterogeneity in Human Capital Investments: High School Curriculum, College Major, and Careers,” Annual Review of Economics, Annual Reviews, 4(1): 185-223.

Angrist, Joshua, David Autor, Sally Hudson, and Amanda Pallais. 2015. "Leveling Up: Early Results from a Randomized Evaluation of Post-Secondary Aid.” The American Economic Review: Papers \& Proceedings, forthcoming May 2015.

Arcidiacono, Peter, V. Joseph Hotz and Songman Kang. 2012. "Modeling college major choices using elicited measures of expectations and counterfactuals.” Journal of Econometrics, 166(1): 3-16.

Apollo Education Group. 2015. "Universidad de Artes, Ciencias y Comunicacion.” http://www.apollo.edu/learning-platforms/apollo-global/uniacc.html. Accessed 5/11/2015.

Avery, Christopher and Thomas J. Kane, 2004. "Student Perceptions of College Opportunities. The Boston COACH Program," NBER Chapters, in: College Choices: The Economics of Where to Go, When to Go, and How to Pay For It, pages 355-394, National Bureau of Economic Research, Inc.

Attanasio, Orazio and Katja Maria Kaufmann. 2014. "Education Choices and Returns to Schooling: Mothers' and Youths' Subjective Expectations and their Role by Gender.” Journal of Development Economics, vol. 109: 203-216.

Barrionuevo, Alexei. 2011. “With Kiss-Ins and Dances, Young Chileans Push for Reform.” The New York Times 4 August 2011.

http://www.nytimes.com/2011/08/05/world/americas/05chile.html?pagewanted=all\&_r=1\&. Accessed 4 March 2015.

Beffy, Magali, Denis Fougére, and Arnaud Maurel. 2012. "Choosing the field of study in postsecondary education: do expected earnings matter?” Review of Economics and Statistics, 94(1): 334-347.

Bettinger, Eric P., Bridget T. Long, Phillip Oreopoulos, L. Sanbonmatsu. 2012. "The role of application assistance and information in college decisiosn: results from the H\&R Block FAFSA experiment.” Quarterly Journal of Economics. 127:1-38.

Betts, Julian. 1996. "What do Students Know about Wages? Evidence for a Survey of Undergraduates.” Journal of Human Resources 31 (1): 25-56.

Beyer, Harald, Justine Hastings, Christopher Neilson and Seth Zimmerman. 2015. "Connecting Student Loans to Labor Market Outcomes: Policy Lessons from Chile.” The American Economic Review: Papers \& Proceedings, 105(5): 508-513.

Bordon, Paola and Chao Fu. Forthcoming. “College-Major Choice to College-then-Major Choice.” Review of Economic Studies.

Cameron, Stephen and James Heckman. 2001. "The Dynamics of Educational Attainment for Black, Hispanic, and White Males,” The Journal of Political Economy: 109(3): 455-499. 
Chade, Hector and Lones Smith. 2006. “Simultaneous Search.” Econometrica, 74(5): 1293-1307.

Deming, David, Claudia Goldin, and Lawrence F. Katz. 2012. "The For-Profit Postsecondary School Sector: Nimble Critters or Agile Predators.” Journal of Economic Perspectives, 25 139-163.

Dinkelman, Taryn and Claudia Martínez. 2014. "Investing in Schooling in Chile: The Role of Information about Financial Aid for Higher Education,” The Review of Economics and Statistics, MIT Press, vol. 96(2): 244-257.

DOE (Department of Education). 2014a. “Obama Administration Announces Final Rules to Protect Students from Poor-Performing Career College Programs.” N.p., 30 Oct. 2014. http://www.ed.gov/news/press-releases/obama-administration-announces-final-rules-protect-studentspoor-performing-care . Accessed 14 November.

DOE (Department of Education). 2014b. "Web Tables: Student Financing of Undergraduate Education 2011-12.” NCES 2015-173. http://nces.ed.gov/pubs2015/2015173.pdf.

Dominitz, Jeff and Charles Manski. 1996. "Eliciting Student Expectations of the Returns to Schooling," Journal of Human Resources, 31(1): 1-26.

Dynarski, Susan. 2003. "Does Aid Matter? Measuring the Effect of Student Aid on College Attendance and Completion.” American Economic Review 93(1): 279-288.

Dynarski, Susan and Judith Scott-Clayton. 2008. "Complexity and Targeting in Federal Student Aid: A Quantitative Analysis.” Tax Policy and the Economy, vol. 22: 109-150.

Dynarski, Susan, Judith Scott-Clayton, and Mark Wiederspan. 2013. "Simplifying Tax Incentives and Aid for College: Progress and Prospects.” Tax Policy and the Economy, vol. 27(1): 161-202.

Finkelstein, Amy, Sarah Taubman, Bill Wright, Mira Bernstein, Jonathan Gruber, Joseph P. Newhouse, Heidi Allen, and Katherine Baicker. 2012. "The Oregon Health Insurance Experiment: Evidence from the First Year.” Quarterly Journal of Economics, 127(3): 1057-1106.

Fryer, Roland. 2014. "Injecting Charter School Best Practices into Traditional Public Schools: Evidence from Field Experiments.” Quarterly Journal of Economics, 129(3): 1355-1407.

Futuro Laboral. 2015. www.mifuturo.cl. Accessed 5/11/2015.

Goodman, Joshua, Michael Hurwitz, and Jonathan Smith. 2015. "College Access, Initial Choice and Degree Completion,” NBER Working Paper 20996.

Grodksy, Eric and Melanie Jones. 2007. "Real and imagined barriers to college entry: Perceptions of cost,” Social Science Research, 36: 745-766.

Hastings, Justine S., and Jeffrey M. Weinstein. 2008. "Information, School Choice, and Academic Achievement: Evidence from Two Experiments." The Quarterly Journal of Economics 123.4: 1373-1414.

Hastings, Justine S. 2015. "Information versus Impatience in Savings for Retirement: Field Experimental Evidence from Mexico’s Privatized Pension Program.” Unpublished manuscript, Brown University. 
Hastings, Justine S., Christopher A. Neilson and Seth D. Zimmerman. 2013. "Are Some Degrees Worth More than Others? Evidence from college admission cutoffs in Chile," NBER Working Paper 19241.

Hastings, Justine S., Christopher A. Neilson and Seth D. Zimmerman. 2015. “The Effects of Earnings Disclosure on College Enrollment Decisions.” NBER Working Paper 21300.

Hoxby, Caroline M. and Christopher Avery. 2012. "The Missing "One-Offs": The Hidden Supply of High-Achieving, Low Income Students.” NBER Working Paper 18586.

Hoxby, Caroline M. and Sarah Turner. 2013. "Expanding College Opportunities for High-Achieving, Low Income Students.” SIEPR Discussion Paper 12-014. March.

Hoxby, Caroline M. and Sarah Turner. 2015. "What High-Achieving Low-Income Students Know About College.” The American Economic Review: Papers \& Proceedings, 105 (5): 514-517.

Jensen, Robert. 2010. “The (Perceived) Returns to Education and the Demand for Schooling.” The Quarterly Journal of Economics, 125(2): 515-548.

Kaufmann, Katja Maria. 2014. "Understanding the income gradient in college attendance in Mexico: The role of heterogeneity in expected returns.” Quantitative Economics, 5: 583-630.

Kirkebøen, Lars, Edwin Leuven, and Magne Mogstad. Field of Study, Earnings, and Self-Selection. NBER Working Paper 20816.

Lusardi, Annamaria, and Olivia Mitchell. 2011. "Financial Literacy: Implications for Retirement Security and the Financial Marketplace.” Oxford University Press, p. 1-13.

Malamud, Ofer. 2011. "Discovering one's talent: learning from academic specialization." Industrial \& Labor Relations Review 64.2: 375-405.

Mineduc 2012a. “Estadisticas de la Educacion 2012.”

Mineduc 2012b. “Otorga Beneficios a los Deudores del Credito con Garantia Estatal y Modifica la Ley No 20.027.” http://www.leychile.cl/N?i=1044419\&f=2012-10-04\&p=. Accessed 3/13/2015.

Neilson, Christopher. 2013. "Targeted Vouchers, Competition Among Schools, and the Academic Achievement of Poor Students.” Unpublished.

Nguyen, Trang. 2010. "Information, Role Models and Perceived Returns to Education: Experimental Evidence from Madagascar,” MIT Working Paper.

OECD (Organization for Economic Co-operation and Development). 2009. "Reviews of National Policies for Education: Tertiary Education in Chile.”

OECD (Organization for Economic Co-operation and Development). 2012. "Education at a Glance:

OECD Indicators.” http://www.oecd.org/edu/EAG\%202012_e-book_EN_200912.pdf. Accessed 4 March 2015.

Oreopoulos, Philip and Ryan Dunn. 2013. "Information and College Access: Evidence from a Randomized Field Experiment,” Scandinavian Journal of Economics, vol. 115(1): 3-26, 01. 
Reyes, Loreto, Jorge Rodríguez, and Sergio S. Urzúa. 2013. “Heterogeneous Economic Returns to Postsecondary Degrees: Evidence from Chile.” NBER Working Paper 18817.

Stinebrickner, Ralph and Todd Stinebrickner. 2014. “A Major in Science? Initial Beliefs and Final Outcomes for College Major and Dropout.” Review of Economic Studies, 81 (1): 426-472.

Wiswall, Matthew and Basit Zafar. 2015. "Determinants of College Major Choices: Identification from an Information Experiment.” Review of Economic Studies 82 (2): 791-824.

White House 2014. "Remarks by the President on Opportunity for All: Making College More Affordable.” June $9^{\text {th }}$ 2014. https://www.whitehouse.gov/the-press-office/2014/06/09/remarks-president opportunity-all-making-college-more-affordable. Accessed 3/13/2015.

World Bank. 2015. “GDP per capita (current US\$).” Table.

http://data.worldbank.org/indicator/ny.gdp.pcap.cd. Accessed 5 March 2015.

Zafar, Basit. 2011. "How do College Students form Expectations?" Journal of Labor Economics, 29(2): 301-348.

Zafar, Basit. 2013. "College Major Choice and the Gender Gap," Journal of Human Resources, vol. 48(3): 545-595.

Zimmerman, Seth. 2014. "The Returns to College Admission for Academically Marginal Students,” Journal of Labor Economics, vol. 32(4) 711-754. 
Table 1. Comparison of Survey Respondents vs. Population

\begin{tabular}{|c|c|c|c|c|}
\hline & \multicolumn{2}{|c|}{ P3E 2011} & \multicolumn{2}{|c|}{$\underline{\mathrm{TNE}}$} \\
\hline & Respondents & Population & Respondents & Population \\
\hline \multirow[t]{2}{*}{ Average entrance exam score } & 539 & 495 & 535 & 513 \\
\hline & $(12,508)$ & $(151,415)$ & $(25,272)$ & $(183,119)$ \\
\hline \multirow[t]{2}{*}{ Graduated from municipal HS } & 42.3 & 47.7 & 37.5 & 43.6 \\
\hline & $(12,724)$ & $(171,651)$ & $(26,225)$ & $(95,763)$ \\
\hline \multirow[t]{2}{*}{ Graduated from voucher HS } & 56.3 & 50.9 & 53.8 & 53.2 \\
\hline & $(12,724)$ & $(171,651)$ & $(26,225)$ & $(95,763)$ \\
\hline \multirow[t]{2}{*}{ Graduated from private HS } & 1.4 & 1.4 & 8.7 & 3.2 \\
\hline & $(12,724)$ & $(171,651)$ & $(26,225)$ & $(95,763)$ \\
\hline \multirow[t]{2}{*}{ Percent low-SES } & 33.5 & 46.6 & 39.6 & 53.8 \\
\hline & $(12,694)$ & $(170,962)$ & $(25,568)$ & $(94,911)$ \\
\hline \multirow[t]{2}{*}{ Federal grant \& loan applicant } & 88.6 & 68.2 & 33 & 27.6 \\
\hline & $(12,730)$ & $(171,651)$ & $(26,424)$ & $(196,321)$ \\
\hline \multirow[t]{2}{*}{ Percent male } & 36.4 & 44.7 & 40.3 & 47.9 \\
\hline & $(12,724)$ & $(171,651)$ & $(26,345)$ & $(187,279)$ \\
\hline \multirow[t]{2}{*}{ Percent graduated high-school before 2011} & 36.7 & 19.3 & 69.6 & 64.5 \\
\hline & $(12,724)$ & $(171,651)$ & $(26,220)$ & $(196,321)$ \\
\hline Total Observations & 12,730 & 171,651 & 26,424 & 196,321 \\
\hline \multicolumn{5}{|c|}{$\begin{array}{l}\text { Notes: All values are reported as percentages, except entrance exam score, which is reported in levels. Number of observations for } \\
\text { each calculation are in parentheses. These values differ from total observations because of partially incomplete administrative data. } \\
\text { Entrance exam scores for each student are the average of the math and reading PSU sections. Student SES status is based on high- } \\
\text { school level SES ranking supplied by Mineduc. See section } 4.2 \text { for details. The P3E } 2011 \text { survey recruited respondents from the } \\
\text { sample of PSU registrants in November-December of 2011. The TNE survey recruited participants from the sample of first-year } \\
\text { post-secondary students, and entrance exam registrants and applicants for the Chilean Federal Student Grants and Loans for the } \\
2012 \text { school year in March-September, 2012. }\end{array}$} \\
\hline
\end{tabular}


Table 2. Survey Expectations for Respondent's First-choice Major

\begin{tabular}{lcccccc}
\hline & \% Did not respond & Mean Error & P25 & Median Error & P75 & $\mathrm{N}$ \\
\cline { 2 - 7 } $\begin{array}{l}\text { Degree costs expectation errors } \\
\text { All students }\end{array}$ & & & & & & \\
\hline Low-SES & 39.6 & 4.7 & -11.2 & -3.5 & 10.9 & 10,722 \\
High-SES & 46.7 & 10.6 & -11.7 & -1.8 & 15.8 & 3,532 \\
\hline Entrance exam [0,500) & $36.1^{* * *}$ & $2.4^{* * *}$ & -11.1 & $-3.8^{* *}$ & $9.2^{* * *}$ & 7,163 \\
Entrance exam [500,600] & 48.2 & 14.1 & -13.1 & -0.9 & 20.0 & 3,153 \\
Entrance exam $(600,850]$ & $39.3^{* * *}$ & $3.3^{* * *}$ & $-11.3^{* *}$ & $-3.3^{* *}$ & $11.0^{* * *}$ & 4,854 \\
\hline
\end{tabular}

Earnings expectation errors for graduates with similar characteristics

\begin{tabular}{lcccccc} 
All students & 12.2 & 39.3 & -9.6 & 19.5 & 63.3 & 11,014 \\
\hline Low-SES & 14.5 & 42.0 & -11.5 & 19.4 & 67.3 & 3,639 \\
High-SES & $11.2^{* * *}$ & $38.1+$ & $-9.0+$ & 19.7 & $61.3^{*}$ & 7,347 \\
\hline Entrance exam [0,500) & 15.5 & 56.0 & -9.3 & 26.0 & 86.4 & 3,238 \\
Entrance exam [500, 600] & $11.5^{* * *}$ & $35.9^{* * *}$ & -10.5 & $18.7^{* * *}$ & $61.3^{* * *}$ & 4,986 \\
Entrance exam $(600,850]$ & $9.4^{* * *}$ & $31.4^{* * *}$ & -8.9 & $16.1^{* * *}$ & $51.4^{* * *}$ & 2,631 \\
\hline
\end{tabular}

Earnings expectation errors for own earnings after graduation

\begin{tabular}{lcccccc} 
All students & 4.7 & 43.2 & -13.9 & 15.6 & 62.4 & 11,014 \\
\hline Low-SES & 5.3 & 49.6 & -16.0 & 15.9 & 66.8 & 3,639 \\
High-SES & $4.4^{*}$ & $40.4^{* *}$ & $-12.8^{*}$ & 15.6 & $60.2^{*}$ & 7,347 \\
\hline Entrance exam [0,500) & 5.2 & 66.0 & -14.9 & 22.7 & 86.4 & 3,238 \\
Entrance exam [500, 600] & 4.6 & $42.4^{* * *}$ & -11.8 & 21.9 & $67.2^{* * *}$ & 4,986 \\
Entrance exam (600, 850] & 4.4 & $24.9^{* * *}$ & -15.1 & $7.3^{* * *}$ & $41.3^{* * *}$ & 2,631 \\
\hline
\end{tabular}

Confidence in expected wages over graduates with similar characteristics

\begin{tabular}{lcccccc} 
All students & 12.3 & 0.3 & -17.0 & -2.4 & 7.7 & 11,014 \\
\hline Low-SES & 14.5 & 2.0 & -17.0 & -2.5 & 7.9 & 3,639 \\
High-SES & $11.2^{* * *}$ & $-0.5^{*}$ & -17.0 & -2.4 & 7.6 & 7,347 \\
\hline Entrance exam [0,500) & 15.5 & 3.3 & -17.5 & -2.1 & 9.4 & 3,238 \\
Entrance exam [500, 600] & $11.5^{* * *}$ & $-0.5^{* *}$ & -16.7 & -2.2 & $7.7+$ & 4,986 \\
Entrance exam $(600,850]$ & $9.5^{* * *}$ & $-2.1^{* * *}$ & -17.9 & $-3.4^{* *}$ & $5.7^{* * *}$ & 2,631 \\
\hline
\end{tabular}

Notes: Did not respond column is the percentage of students not providing an expectation in response to questions about the listed cost or earnings expectation. All other columns reflect percentage deviations of stated expectations from benchmark values: $100 X$ (Expected-

Benchmark)/Benchmark). Cost benchmarks are computed using 2012 administrative data on tuition and fees. Earnings benchmarks are based on administrative tax data. See sections 4.2 and 5.2 for a discussion of benchmarking procedures. Table draws on survey questions 3, 5, 7, and 9 from 3Ev1 survey; see Online Appendix for survey text. Student SES status is based on high-school level SES ranking supplied by Mineduc. See section 4.2 for details. Entrance exam score is the average of the Math and Language components of the PSU admissions test. Sample sizes reported in the last column count all those who answered the question and all respondents not providing responses. Significance tests are performed for the difference between values for high-SES relative to low-SES students and for the entrance exam categories [500,600] and $(600,850]$ relative to [0,500). Significance test results are reported as: $+\mathrm{p}<0.10, * \mathrm{p}<0.05, * * \mathrm{p}<0.01, * * * \mathrm{p}<0.001$. 
Table 3. Knowledge of Alternative Higher Education Enrollment Suggestions

\begin{tabular}{|c|c|c|c|c|c|c|}
\hline & All Students & Low-SES & High-SES & Exam [0,500) & Exam $[500,600]$ & $\begin{array}{l}\text { Exam } \\
(600,850]\end{array}$ \\
\hline \multicolumn{7}{|c|}{ Knowledge of alternative suggestions } \\
\hline \multicolumn{7}{|c|}{ Same field as first-choice major } \\
\hline Know nothing & 39.0 & 43.3 & $37.0 * * *$ & 43.6 & $39.0 * * *$ & $34.2 * * *$ \\
\hline Know some & 43.7 & 42.6 & 44.1 & 42.6 & 43.3 & $45.1+$ \\
\hline Know a lot & 17.4 & 14.1 & $18.9 * * *$ & 13.8 & $17.7^{* * * *}$ & $20.7^{* * *}$ \\
\hline $\mathrm{N}$ & 7,179 & 2,207 & 4,951 & 1,849 & 3,329 & 1,900 \\
\hline \multicolumn{7}{|c|}{ Different field than first-choice major } \\
\hline Know nothing & 66.4 & 65.6 & 66.8 & 66.3 & $67.8+$ & $64.6+$ \\
\hline Know some & 27.9 & 29.0 & $27.3 *$ & 29.0 & $26.6^{* * *}$ & 28.6 \\
\hline Know a lot & 5.7 & 5.4 & 5.9 & 4.8 & $5.6^{*}$ & $6.8 * * *$ \\
\hline $\mathrm{N}$ & 7,456 & 2,300 & 5,133 & 1,952 & 3,449 & 1,951 \\
\hline \multicolumn{7}{|c|}{$\begin{array}{l}\text { Notes: All values are reported as percentages. Upper panel: respondents were asked how familiar they were with a list of alternative top } \\
\text { earning majors offered at a particular institution type (university, technical, professional) in the same field as their previously elicited top } \\
\text { preferences. Lower panel: They were also suggested alternatives that were the top earning majors from any field, outside of the ones previously } \\
\text { elicited. See section } 5.3 \text { for more details on the process for choosing alternative degrees. The "Know nothing” category combines two response } \\
\text { options: never having heard of the career and having heard of it, but know little or nothing about it. Full Question text and response options are } \\
\text { available in the Appendix. Student SES status is based on high-school level SES ranking supplied by Mineduc. See section } 4.2 \text { for details. } \\
\text { Exam is the average score for the Math and Language components of PSU college entrance exam. Significance tests are performed for the } \\
\text { difference between values for high-SES relative to low-SES students and for the entrance exam categories [500,600] and (600,850] relative to } \\
{[0,500) \text {. Significance test results are reported as: }+p<0.10,{ }^{*} p<0.05 \text {, }{ }^{* *} p<0.01 \text {, }{ }^{* * *} p<0.001 \text {. }}\end{array}$} \\
\hline
\end{tabular}


Table 4. Relationship Between Expectation Errors And Enrollment Choices

\begin{tabular}{|c|c|c|c|c|c|c|}
\hline & $\begin{array}{c}\text { Matriculate } \\
2012 \\
\end{array}$ & $\begin{array}{l}\text { Matriculate to } \\
\text { First-Choice }\end{array}$ & $\begin{array}{c}\text { Dropout after } \\
\text { 1st Year Enroll }\end{array}$ & $\begin{array}{c}\text { Age } 26 \text { Matriculated } \\
\text { Degree Earnings }\end{array}$ & $\begin{array}{c}\text { Degree } \\
\text { Default Rate }\end{array}$ & $\begin{array}{c}\text { Degree Graduation } \\
\text { Rate }\end{array}$ \\
\hline \multicolumn{7}{|c|}{ Earnings expectation for own earnings after graduation } \\
\hline \multirow[t]{2}{*}{ Overestimate } & -0.007 & 0.010 & 0.010 & $-80,209 * * *$ & $0.023 * * *$ & $-0.021^{*}$ \\
\hline & $(0.013)$ & $(0.015)$ & $(0.009)$ & $(9,827)$ & $(0.007)$ & $(0.009)$ \\
\hline \multirow[t]{2}{*}{ Underestimate } & -0.014 & -0.013 & -0.013 & $58,153 * * *$ & -0.007 & 0.001 \\
\hline & $(0.018)$ & $(0.018)$ & $(0.010)$ & $(14,327)$ & $(0.008)$ & $(0.012)$ \\
\hline \multicolumn{7}{|c|}{ Degree costs expectation } \\
\hline \multirow[t]{2}{*}{ Overestimate } & $-0.055^{* *}$ & $-0.077 * * *$ & $0.033^{*}$ & $-17,716$ & $0.018 *$ & -0.019 \\
\hline & $(0.021)$ & $(0.018)$ & $(0.015)$ & $(13,586)$ & $(0.009)$ & $(0.014)$ \\
\hline \multirow[t]{2}{*}{ Underestimate } & -0.031 & $-0.040+$ & 0.020 & $-24,122$ & 0.001 & 0.009 \\
\hline & $(0.023)$ & $(0.022)$ & $(0.017)$ & $(15,584)$ & $(0.011)$ & $(0.014)$ \\
\hline $\mathrm{N}$ & 4,042 & 4,042 & 3,292 & 2,872 & 1,838 & 2,957 \\
\hline \multicolumn{7}{|c|}{$\begin{array}{l}\text { Notes: Linear regressions of variables listed in column on variables listed in rows, as well as additional controls for gender, student SES, and second-order } \\
\text { polynomial in test score. In the earnings panel, the Overestimate (Underestimate) rows report estimated effects of dummy variables equal to one if a } \\
\text { respondent overestimates (underestimates) his/her own earnings relative to the benchmark earnings value by more than } 25 \% \text { (less than }-25 \% \text { ). The omitted } \\
\text { category is students with expectations within } 25 \% \text { of the benchmark value. The costs panel dummies are defined analogously based on cost expectations } \\
\text { and benchmark values. Matriculate } 2012 \text { is a dummy equal to one if a student matriculated anywhere in } 2012 \text {. Matriculate to first choice is a dummy equal } \\
\text { to one if a student matriculated at his/her stated first choice. Dropout after } 1^{\text {st }} \text { year enroll is a dummy equal to one if a student who enrolls in some degree } \\
\text { program in } 2012 \text { does not re-enroll in postsecondary education in } 2013 \text {. Age } 26 \text { matriculated degree earnings is degree- and demographic-group specific } \\
\text { OLS prediction or earnings outcomes based on those for past students. Units are } 2011 \text { CLP. Degree default rate is a degree-level measure of default rates } \\
\text { (at least } 3 \text { payments behind) on CAE loans for students who have entered repayment as of April } 2013 \text {. Degree graduation rate is the percent of the } 2000 \text { - } \\
2005 \text { freshmen cohorts who complete a postsecondary degree. See sections } 4.1 \text { and } 4.2 \text { and Online Appendix } 6 \text { for more information on administrative data } \\
\text { sources. Survey data are from 3Ev1 questions } 3,5 \text {, and } 7 \text {; see Online Appendix for survey text. Robust standard errors are reported in parentheses. } \\
\text { Significance test results are reported as: }+p<0.10, * p<0.05, * * p<0.01, * * * p<0.001 \text {. }\end{array}$} \\
\hline
\end{tabular}


Table 5. Sources of Career Choice Information

\begin{tabular}{|c|c|c|c|c|c|c|}
\hline & All Students & Low-SES & High-SES & Exam $[0,500)$ & Exam $[500,600]$ & Exam $(600,850]$ \\
\hline \multicolumn{7}{|c|}{ Top three important sources of information } \\
\hline Government websites & 35.4 & 36.4 & $34.9+$ & 30.7 & $38.2 * * *$ & $36.4 * * *$ \\
\hline Peers/family & 51.9 & 51.1 & 52.3 & 54.6 & $49.4^{* * *}$ & 53.1 \\
\hline Publicity/advertisements & 34.9 & 37.0 & $33.7^{* * *}$ & 38.1 & $34.6^{* * *}$ & $31.5^{* * *}$ \\
\hline Teachers/school orientation & 33.3 & 32.2 & $33.9 *$ & 29.5 & $33.0 * * *$ & $37.1 * * *$ \\
\hline Institution's website & 32.3 & 32.8 & 32.0 & 29.9 & $33.9 * * *$ & $33.8^{* * *}$ \\
\hline Visit to institution & 33.2 & 34.4 & $32.6^{*}$ & 37.2 & $32.6^{* * *}$ & $30.2^{* * *}$ \\
\hline Conferences at school & 40.1 & 33.9 & $43.6^{* * *}$ & 37.8 & $39.6^{*}$ & $42.4^{* * *}$ \\
\hline Other & 17.6 & 18.4 & $17.2+$ & 19.1 & $17.6^{*}$ & $16.5^{* *}$ \\
\hline Observations & 17,054 & 6,192 & 10,862 & 5,213 & 7,425 & 4,329 \\
\hline \multicolumn{7}{|c|}{$\begin{array}{l}\text { Notes: All values are reported as percentages. Responses to prompts to rank lists of possible information sources by importance in college search process. } \\
\text { Table combines results for 3Ev1 and TNE surveys. "Institution's website" category was not given as an option in the P3E } 2011 \text { survey. Several of the } \\
\text { above categories combine response options; see Online Appendix } 6 \text { for details. Each question's text and response options are available in the Online } \\
\text { Appendix. Student SES status is based on high-school level SES ranking supplied by Mineduc. See section } 4.2 \text { for details. Exam score is the average of the } \\
\text { Math and Language components of the PSU admissions test. Significance tests are performed for the difference between values of low-SES versus high- } \\
\text { SES and each of the entrance exam categories [500,600] and }(600,850] \text { versus [0,500). Significance test results are reported as: + }<<0.10,{ }^{*} p<0.05 \text {, }{ }^{* *} \text { p }< \\
0.01,{ }^{* * *} \text { p }<0.001 \text {. }\end{array}$} \\
\hline
\end{tabular}


Table 6. Top Three Factors Considered in Institution and Major Choice

\begin{tabular}{|c|c|c|c|c|c|c|}
\hline & All Students & Low-SES & High-SES & Exam $[0,500)$ & Exam $[500,600]$ & Exam $(600,850]$ \\
\hline \multicolumn{7}{|l|}{ Institution choice } \\
\hline Prestige & 63.6 & 54.9 & $68.5^{* * *}$ & 49.9 & $62.6^{* * *}$ & $81.8^{* * *}$ \\
\hline Accreditation & 60.8 & 63.5 & $59.3 * * *$ & 62.5 & $64.3^{*}$ & $53.5^{* * *}$ \\
\hline Good publicity & 7.6 & 10.4 & $5.9 * * *$ & 12.3 & $6.8^{* * *}$ & $2.8 * * *$ \\
\hline Infrastructure/technology & 18.2 & 16.1 & $19.3^{* * *}$ & 18.0 & 18.0 & 19.1 \\
\hline Curriculum offerings & 25.7 & 21.6 & $27.3^{* * *}$ & 25.0 & 25.3 & 27.3 \\
\hline Type of work & 8.8 & 9.9 & 8.3 & 10.2 & $8.2+$ & 8.8 \\
\hline Employment prospects & 33.7 & 31.8 & $34.8 * * *$ & 32.6 & $30.7^{*}$ & $39.4^{* * *}$ \\
\hline Future earnings & 11.1 & 9.2 & $12.2^{* * *}$ & 9.3 & 10.0 & $15.1 * * *$ \\
\hline Location & 20.1 & 23.9 & $17.9 * * *$ & 22.4 & 21.2 & $15.8 * * *$ \\
\hline Low costs & 23.8 & 29.1 & $20.9 * * *$ & 32.6 & $25.0 * * *$ & $11.3^{* * *}$ \\
\hline Financing availability & 20.6 & 23.3 & $19.1^{* * *}$ & 21.6 & 21.6 & $17.7 * * *$ \\
\hline People like me attend & 8.6 & 8.9 & 8.4 & 9.5 & $8.6^{+}$ & $7.3 * * *$ \\
\hline Extracurricular & 5.9 & 6.2 & 5.7 & 8.2 & $5.0 * * *$ & $4.4^{* * *}$ \\
\hline Other & 10.4 & 11.5 & $9.7 * * *$ & 11.5 & $10.5+$ & $9.5^{* *}$ \\
\hline Observations & 17,046 & 6,133 & 10,913 & 5,186 & 7,387 & 4,377 \\
\hline \multicolumn{7}{|l|}{ Major choice } \\
\hline Prestige & 34.5 & 34.7 & 34.4 & 33.7 & 33.0 & $37.9 * * *$ \\
\hline Employment prospects & 43.5 & 47.5 & $41.3^{* * *}$ & 47.1 & $43.1^{* * *}$ & $39.5^{* * *}$ \\
\hline Future earnings & 29.0 & 27.7 & $29.7^{* *}$ & 24.9 & $29.4 * * *$ & $32.5^{* * *}$ \\
\hline Good publicity & 6.3 & 8.1 & $5.3^{* * *}$ & 9.5 & $5.6^{* * *}$ & $3.3^{* * *}$ \\
\hline Low costs & 15.6 & 20.8 & $12.6 * * *$ & 23.4 & $14.9 * * *$ & $7.1^{* * *}$ \\
\hline People like me attend & 7.1 & 7.8 & $6.7 * *$ & 7.8 & $6.8^{*}$ & $6.4^{* *}$ \\
\hline Curriculum offerings & 36.7 & 30.6 & $40.2^{* * *}$ & 32.1 & $38.9 * * *$ & $39.2 * * *$ \\
\hline Type of work & 84.1 & 81.7 & $85.4 * * *$ & 80.8 & $84.8 * * *$ & $87.1^{* * *}$ \\
\hline Other & 12.1 & 12.1 & 12.2 & 12.2 & 12.4 & 11.6 \\
\hline Observations & 17,125 & 6,198 & 10,927 & 5,220 & 7,459 & 4,355 \\
\hline
\end{tabular}


Table 7. Financial Literacy \& State-Backed Loan Knowledge

\begin{tabular}{|c|c|c|c|c|c|c|}
\hline & All Students & Low-SES & High-SES & Exam $[0,500)$ & Exam $[500,600]$ & Exam $(600,850]$ \\
\hline \multicolumn{7}{|c|}{ General Financial Literacy } \\
\hline \% Correct & 44.2 & 42.8 & 45.2 & 38.3 & 45.5 & 49.6 \\
\hline \% I Don't Know & 23.7 & 24.6 & 23.2 & 28.8 & 23.8 & 16.8 \\
\hline $\mathrm{N}$ & 6,295 & 2,350 & 3,758 & 1,963 & 2,656 & 1,439 \\
\hline \multicolumn{7}{|c|}{ Literacy of State-backed Loan Policy } \\
\hline \% Correct & 37.3 & 36.4 & 38.0 & 34.0 & 40.1 & 38.6 \\
\hline \% I Don't Know & 32.6 & 32.2 & 32.8 & 34.3 & 29.0 & 34.9 \\
\hline $\mathrm{N}$ & 6,177 & 2,298 & 3,698 & 1,901 & 2,627 & 1,418 \\
\hline \multicolumn{7}{|c|}{$\begin{array}{l}\text { Notes: Responses to test questions on financial literacy and knowledge of state-backed loans from TNE version C. All values are reported as } \\
\text { percentages. \% Correct is the number of correct answers as a percent of the number of questions answered (up to } 2 \text { questions for financial } \\
\text { literacy; up to } 3 \text { questions for state-based loans). Questions from upper panel dealt with interest rates and inflation; questions from lower panel } \\
\text { dealt with loan interest rates, grace periods, and interest accrual. See section } 5.5 \text { for a discussion of questions. Text and response options for } \\
\text { these questions are available in the Online Appendix; see Table A5 for question-by-question breakdown. Student SES status is based on high- } \\
\text { school level SES ranking supplied by Mineduc. Exam score is the average of the Math and Language components of the PSU admissions exam. } \\
\text { See section } 4.2 \text { for details. }\end{array}$} \\
\hline
\end{tabular}


Table 8. Information sources, preferences, and earnings and cost expectations

\begin{tabular}{|c|c|c|c|c|c|c|}
\hline & \multicolumn{3}{|c|}{ Own Earnings Expectations } & \multicolumn{3}{|c|}{ Degree Costs Expectations } \\
\hline & Overestimate & Underestimate & Accurate & Overestimate & Underestimate & Accurate \\
\hline \multicolumn{7}{|l|}{ Sources of Degree Information } \\
\hline \multirow[t]{2}{*}{ Government website } & -0.016 & $-0.021 *$ & $0.038 * *$ & -0.004 & $-0.015+$ & 0.019 \\
\hline & $(0.013)$ & $(0.010)$ & $(0.013)$ & $(0.011)$ & $(0.009)$ & $(0.013)$ \\
\hline \multirow[t]{2}{*}{ Publicity/advertisements } & 0.004 & -0.004 & 0.000 & -0.011 & $-0.016+$ & $0.027^{*}$ \\
\hline & $(0.013)$ & $(0.010)$ & $(0.013)$ & $(0.011)$ & $(0.009)$ & $(0.013)$ \\
\hline \multirow[t]{2}{*}{ Teachers/school orientation } & 0.001 & -0.009 & 0.008 & 0.008 & 0.012 & -0.020 \\
\hline & $(0.013)$ & $(0.010)$ & $(0.013)$ & $(0.011)$ & $(0.009)$ & $(0.013)$ \\
\hline \multirow[t]{2}{*}{ Conferences at school } & $-0.022+$ & $0.024^{*}$ & -0.002 & -0.006 & 0.007 & -0.001 \\
\hline & $(0.013)$ & $(0.010)$ & $(0.013)$ & $(0.011)$ & $(0.009)$ & $(0.013)$ \\
\hline \multirow[t]{2}{*}{ Visit to institution } & 0.004 & $-0.016+$ & 0.012 & $-0.019+$ & -0.010 & $0.030 *$ \\
\hline & $(0.013)$ & $(0.010)$ & $(0.014)$ & $(0.011)$ & $(0.009)$ & $(0.013)$ \\
\hline \multicolumn{7}{|c|}{ Factors Considered in Enrollment Decision } \\
\hline \multirow[t]{2}{*}{ Degree costs } & $0.026+$ & -0.010 & -0.016 & $0.029 *$ & 0.012 & $-0.041 * *$ \\
\hline & $(0.014)$ & $(0.010)$ & $(0.014)$ & $(0.012)$ & $(0.010)$ & $(0.015)$ \\
\hline \multirow[t]{2}{*}{ Earnings/job opportunities } & $-0.036 * *$ & $0.018+$ & 0.018 & $-0.023 *$ & -0.002 & $0.025+$ \\
\hline & $(0.013)$ & $(0.010)$ & $(0.013)$ & $(0.011)$ & $(0.009)$ & $(0.014)$ \\
\hline \multirow[t]{2}{*}{ Financing availability } & -0.014 & 0.013 & 0.001 & -0.008 & 0.003 & 0.005 \\
\hline & $(0.015)$ & $(0.011)$ & $(0.015)$ & $(0.013)$ & $(0.011)$ & $(0.015)$ \\
\hline \multirow[t]{2}{*}{ Curriculum offerings } & $0.032 *$ & 0.000 & $-0.032 *$ & 0.002 & 0.000 & -0.002 \\
\hline & $(0.013)$ & $(0.010)$ & $(0.014)$ & $(0.011)$ & $(0.009)$ & $(0.014)$ \\
\hline \multirow[t]{2}{*}{ Type of work } & -0.022 & -0.010 & $0.032 *$ & -0.003 & -0.008 & 0.012 \\
\hline & $(0.014)$ & $(0.011)$ & $(0.015)$ & $(0.012)$ & $(0.010)$ & $(0.015)$ \\
\hline Observations & 7,687 & 7,687 & 7,687 & 5,236 & 5,236 & 5,236 \\
\hline \multicolumn{7}{|c|}{$\begin{array}{l}\text { Notes: Results from regressions of dependent variables listed in column headings on dummies for information sources and stated preferences } \\
\text { listed in rows. Additional controls for student gender, SES, and a second-order polynomial in PSU admissions test score. Each column reflects } \\
\text { results from a single regression. Sources of degree information controls are dummy variables equal to one if a student ranked a source of the given } \\
\text { type among his/her top three most important sources of information during college choice. Factors considered in enrollment decision are dummy } \\
\text { variables equal to one if a student ranked the listed degree attribute among his/her top three highest priorities. Overestimates (underestimates) of } \\
\text { earnings and costs are dummy variables equal to one if a student's expected value was more than } 25 \% \text { above (more than } 25 \% \text { below) the } \\
\text { benchmark from administrative tax and tuition data. Accurate expectations are those where expectations are within } 25 \% \text { of the benchmark value. } \\
\text { See section } 4.1 \text { and } 4.2 \text { and Online Appendix section } 6 \text { for more information on data administrative data sources. Survey data are from } 3 E v 1 \text {; see } \\
\text { Online appendix for survey text. Robust standard errors in parentheses. }+\mathrm{p}<0.10,{ }^{*} \mathrm{p}<0.05,{ }^{* *} \mathrm{p}<0.01 \text {, }{ }^{* * *} \mathrm{p}<0.001 \text {. }\end{array}$} \\
\hline
\end{tabular}


Table 9. Information sources, preferences, and academic outcomes

\begin{tabular}{|c|c|c|c|c|c|c|}
\hline & $\begin{array}{l}\text { Matriculate } \\
2012\end{array}$ & $\begin{array}{l}\text { Matriculate } \\
\text { to First- } \\
\text { Choice }\end{array}$ & $\begin{array}{c}\text { Dropout } \\
\text { after 1st } \\
\text { Year Enroll }\end{array}$ & $\begin{array}{c}\text { Age } 26 \\
\text { Matriculated } \\
\text { Degree } \\
\text { Earnings }\end{array}$ & $\begin{array}{c}\text { Degree } \\
\text { Default } \\
\text { Rate }\end{array}$ & $\begin{array}{c}\text { Degree } \\
\text { Graduation } \\
\text { Rate }\end{array}$ \\
\hline \multicolumn{7}{|c|}{ Sources of Degree Information } \\
\hline Government website & $\begin{array}{c}0.000 \\
(0.010)\end{array}$ & $\begin{array}{c}-0.023^{* *} \\
(0.009)\end{array}$ & $\begin{array}{c}0.006 \\
(0.007)\end{array}$ & $\begin{array}{c}6,895 \\
(7,175)\end{array}$ & $\begin{array}{c}-0.014^{* *} \\
(0.005)\end{array}$ & $\begin{array}{c}0.006 \\
(0.006)\end{array}$ \\
\hline Publicity/advertisements & $\begin{array}{l}-0.001 \\
(0.010)\end{array}$ & $\begin{array}{c}0.005 \\
(0.009)\end{array}$ & $\begin{array}{c}0.004 \\
(0.007)\end{array}$ & $\begin{array}{c}6,263 \\
(7,232)\end{array}$ & $\begin{array}{c}-0.009 * \\
(0.005)\end{array}$ & $\begin{array}{l}-0.013 * \\
(0.006)\end{array}$ \\
\hline $\begin{array}{l}\text { Teachers/school } \\
\text { orientation }\end{array}$ & $\begin{array}{l}-0.001 \\
(0.010)\end{array}$ & $\begin{array}{l}-0.001 \\
(0.008)\end{array}$ & $\begin{array}{c}0.001 \\
(0.007)\end{array}$ & $\begin{array}{c}1,786 \\
(6,949)\end{array}$ & $\begin{array}{l}-0.002 \\
(0.004)\end{array}$ & $\begin{array}{c}0.007 \\
(0.006)\end{array}$ \\
\hline Conferences at school & $\begin{array}{l}-0.010 \\
(0.010)\end{array}$ & $\begin{array}{c}0.001 \\
(0.008)\end{array}$ & $\begin{array}{l}-0.007 \\
(0.007)\end{array}$ & $\begin{array}{l}-6,401 \\
(7,053)\end{array}$ & $\begin{array}{c}0.002 \\
(0.004)\end{array}$ & $\begin{array}{c}0.006 \\
(0.006)\end{array}$ \\
\hline Visit to institution & $\begin{array}{c}0.013 \\
(0.010)\end{array}$ & $\begin{array}{c}0.007 \\
(0.009)\end{array}$ & $\begin{array}{l}-0.001 \\
(0.007)\end{array}$ & $\begin{array}{c}4,408 \\
(7,197)\end{array}$ & $\begin{array}{c}0.007 \\
(0.005)\end{array}$ & $\begin{array}{l}-0.011+ \\
(0.006)\end{array}$ \\
\hline \multicolumn{7}{|c|}{ Factors Considered in Enrollment Decision } \\
\hline Degree costs & $\begin{array}{c}0.009 \\
(0.010)\end{array}$ & $\begin{array}{l}-0.006 \\
(0.009)\end{array}$ & $\begin{array}{c}0.001 \\
(0.007)\end{array}$ & $\begin{array}{c}-16,881^{*} \\
(7,349)\end{array}$ & $\begin{array}{l}0.008+ \\
(0.005)\end{array}$ & $\begin{array}{l}-0.013 * \\
(0.007)\end{array}$ \\
\hline Earnings/job opportunities & $\begin{array}{l}-0.001 \\
(0.010)\end{array}$ & $\begin{array}{l}-0.007 \\
(0.009)\end{array}$ & $\begin{array}{l}-0.006 \\
(0.007)\end{array}$ & $\begin{array}{c}40,955^{* * *} \\
(7,227)\end{array}$ & $\begin{array}{l}-0.002 \\
(0.005)\end{array}$ & $\begin{array}{l}-0.015^{*} \\
(0.006)\end{array}$ \\
\hline Financing availability & $\begin{array}{c}0.005 \\
(0.011)\end{array}$ & $\begin{array}{l}-0.012 \\
(0.009)\end{array}$ & $\begin{array}{l}-0.008 \\
(0.007)\end{array}$ & $\begin{array}{c}2,421 \\
(7,885)\end{array}$ & $\begin{array}{l}-0.001 \\
(0.005)\end{array}$ & $\begin{array}{c}0.006 \\
(0.007)\end{array}$ \\
\hline Curriculum offerings & $\begin{array}{l}0.024^{*} \\
(0.010)\end{array}$ & $\begin{array}{c}0.009 \\
(0.009)\end{array}$ & $\begin{array}{c}0.001 \\
(0.007)\end{array}$ & $\begin{array}{c}-33,589 * * * \\
(7,314)\end{array}$ & $\begin{array}{l}0.008+ \\
(0.005)\end{array}$ & $\begin{array}{l}-0.004 \\
(0.006)\end{array}$ \\
\hline Type of work & $\begin{array}{l}-0.010 \\
(0.011)\end{array}$ & $\begin{array}{l}0.019 * \\
(0.009)\end{array}$ & $\begin{array}{c}0.003 \\
(0.007)\end{array}$ & $\begin{array}{c}-18,065^{*} \\
(7,776)\end{array}$ & $\begin{array}{c}0.000 \\
(0.005)\end{array}$ & $\begin{array}{c}0.023 * * * \\
(0.006)\end{array}$ \\
\hline Observations & 12,478 & 10,829 & 9,442 & 8,106 & 5,195 & 8,295 \\
\hline
\end{tabular}

Notes: Results from regressions of dependent variables listed in column headings on independent variables listed in rows. Additional controls for student gender, SES, and a second-order polynomial in PSU admissions test score. Sources of degree information controls are dummy variables equal to one if a student ranked a source of the given type among his/her top three most important sources of information during college choice. Factors considered in enrollment decision are dummy variables equal to one if a student ranked the listed degree attribute among his/her top three highest priorities. Matriculate 2012 is a dummy equal to one if a student matriculated anywhere in 2012. Matriculate to first choice is a dummy equal to one if a student matriculated at his/her stated first choice. Dropout after $1^{\text {st }}$ year enroll is a dummy equal to one if a student who enrolls in some degree program in 2012 does not re-enroll in postsecondary education in 2013 . Age 26 matriculated degree earnings is degree- and demographic-group specific OLS prediction or earnings outcomes based on those for past students. Units are 2011 CLP. Degree default rate is a degree-level measure of default rates (at least 3 payments behind) on CAE loans for students who have entered repayment as of April 2013. Degree graduation rate is the percent of the 2000-2005 freshmen cohorts who complete a postsecondary degree. See section 4.1 and 4.2 and Online Appendix section 6 for more information on data administrative data sources. Survey data are from 3Ev1; see Online Appendix for survey text. Robust standard errors in parentheses. $+\mathrm{p}<0.10,{ }^{*} \mathrm{p}<0.05,{ }^{* *} \mathrm{p}<0.01,{ }^{* * *} \mathrm{p}<0.001$. 